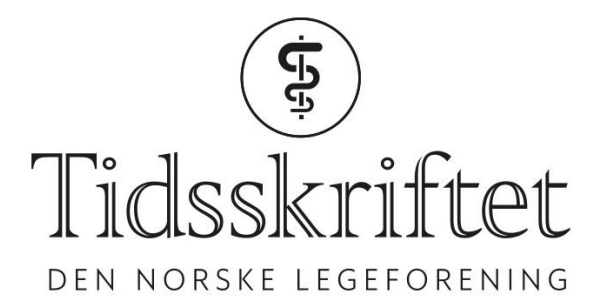

\title{
Den grunnleggende veiledningen i psykoterapi bør bestå
}

KOMMENTAR

PER VAGLUM

E-post: per.vaglum@medisin.uio.no

Per Vaglum er professor emeritus og dr.med.

Ingen oppgitte interessekonflikter.

«Blivende psykiatere bør få veiledning i både psykodynamisk og kognitiv terapi» skriver Erik Falkum (1). Dette utsagn er ingen uenig i. Hvorfor da et debattinnlegg? Falkum omtaler sitt standpunkt i en intern debatt om de nye spesialistreglene i psykiatri, uten en saklig redegjørelse for de utallige høringsuttalelser som hadde et annet syn. For kolleger fra andre spesialiteter vil jeg kort redegjøre for hva uenigheten dreier seg om.

Psykiatri baserer seg på en biopsykososial modell. I dagens spesialistutdanning dekkes "psykodelen» dels av psykologisk teori, dels av to innledende år med grunnleggende veiledning i kliniske samtaler med alle slags pasienter med alle slags diagnoser og behandlingstiltak. I tillegg gis det en ettårig første opplæring i en spesifikk psykoterapeutisk metode: psykodynamisk korttidspsykoterapi, kognitiv psykoterapi eller gruppeterapi. Hver av disse passer bare for et mindre utvalg av pasientene. Dessverre har LIS-legene hittil måttet velge mellom de tre formene for terapi. LIS-legen bør i stedet få ett års erfaring med hver av dem.

Hvor er uenigheten? Falkum vil fjerne de to første årenes grunnleggende veiledning i kliniske samtaler med alle slags pasienter fordi den er basert på psykodynamisk teori. Denne veletablerte veiledningen gir imidlertid ikke veiledning i spesifikk psykodynamisk terapi, men skal sette den kommende spesialisten i stand til å bruke psykodynamisk forståelse der dette er nødvendig for å gjøre de vanlige samtalene med alle typer pasienter mest mulig effektive og funksjonelle, og $ø$ ke etterlevelsen av alle slags behandlinger. Med den grunnleggende veiledningen skal LIS-legene utvikle en kompetanse blant annet i å etablere en god samarbeidsallianse med selv de sykeste pasienter, og kunne identifisere og håndtere bevisste og ubevisste motstandsfenomener som også hindrer gode relasjoner ellers i livet. Dessuten skal veiledningen utvikle en forståelse av psykiske lidelser sett i et familie- og livsløpsperspektiv, hvordan personlighetsfaktorer påvirker både det psykopatologiske bildet og etterlevelse av behandling, og hvordan ubearbeidete traumer, repetering av uheldige internaliserte relasjoner, dysfunksjonell tilknytningsevne, mentalisering og forsvarsmekanismer kan påvirke enhver pasients psykiske lidelse og etterlevelse av alle former for behandling.

Denne grunnleggende veiledningen baseres naturligvis på en teori og en erfaring som rommer alt dette (og mer til), nemlig den psykodynamiske. Spesifikke psykoterapiformer, 
som for eksempel kognitiv, løsningsorientert, emosjonsfokusert og dialektisk, konsentrerer seg bare om begrensede deler. For at den grunnleggende veiledningen skal bety noe mer enn «common sense», gis den nå av psykiatere som er spesialutdannet i å bruke psykodynamisk forståelse, også av det irrasjonelle mennesket. Min konklusjon er at den toårige grunnleggende veiledning bør opprettholdes, og at LIS-legene i tillegg får erfaring med alle de tre spesifikke psykoterapimetodene. Dette gir en klart bedre spesialistutdanning. Legeforeningen må snarest på banen.

\section{LITTERATUR:}

1. Falkum E. Blivende psykiatere bør få veiledning i både psykodynamisk og kognitiv terapi. Tidsskr Nor Legeforen 2018; 138: doi: 10.4045/tidsskr.18.0332. [PubMed][CrossRef]

Publisert: 15. oktober 2018. Tidsskr Nor Legeforen. DOI: 10.4045/tidsskr.18.0736

(C) Tidsskrift for Den norske legeforening 2020. Lastet ned fra tidsskriftet.no 